\title{
The Contribution of Perceived Father Involvement towards Relational Self- Esteem in Early Adolescence
}

\author{
Sarah Diori ${ }^{1}$, Eko Handayani ${ }^{2 *}$ \\ ${ }^{1,2 .}$ Faculty of Psychology, Universitas Indonesia, Depok, Indonesia \\ *E-mail: handayanieko2@gmail.com
}

\begin{abstract}
In early adolescence, children experience significant changes in several aspects of their lives, including changes in social relationship, whether in relationship with family or friends. Those changes may cause adolescents to encounter adaptation problems. Adolescents need a positive relational self-esteem to adapt well to changes. This study examined the contribution of perceived father involvement towards relational self-esteem in early adolescence. Father involvement was measured using Nurturant Fathering Scale and Father Involvement Scale (Reported), while relational self-esteem was measured using Relational SelfEsteem Scale. The participants of this study were adolescents aged 12-15 years $(N=162)$. The results indicated that father nurturance was a significant predictor of relational self-esteem but father involvement was not. In addition, relational self-esteem was neither affected by children's characteristics, such as age or gender, nor by family size and parent's characteristics, such as age, occupation, and education level.
\end{abstract}

Keywords: Early Adolescence; Perceived Father Involvement; Relational Self-Esteem

\section{Introduction}

As children enter the phase of early adolescence, they experience significant changes that are marked by puberty. Although physical changes are the most pronounced in early adolescence, changes also occur in the social relationship with others (Feiring \& Lewis, 1991). Changes in social relationship in early adolescence can be seen in terms of relationship with family and peer (Fuglini \& Eccles, 1993). Social changes, especially in early adolescence, can cause distress (Erath, Flanagan, \& Bierman, 2007). Santrock (2014) also said that adolescents' desire to be accepted could cause not only stress but also anxiety. Therefore, adolescents need to have a better capability to adapt with social changes that are happening in their lives (Yomtov, Plunkett, Sands, \& Reid, 2015).

There are two indicators of positive adaptation according to Yomtov et al. (2015), general selfefficacy and relational self-esteem. General selfefficacy is a person's ability to set and achieve goals even when confronted by challenges (Tong \& Song, 2004). Relational self-esteem is self-evaluation based on the person's relationship with significant others, which are family and friends $(\mathrm{Du}, \mathrm{Li}, \mathrm{Chi}$, Zhao, \& Zhao, 2014). From the definitions of the two constructs, relational self-esteem is argued to be more beneficial for adolescents who are going through significant social changes in their lives. Chen, Broucher, and Kraus (2011) suggest that relational self or relational self-esteem is about the way an individual interacts with their surroundings. If the individual has a positive relational self-esteem, they can establish harmonious relationships with significant others.

The importance of building a harmonious relationship with other people can be influenced by culture. Indonesia, according to Putera and Brill (as cited in Abbott, 2017), has a deep sense of collectivism. Abbott (2017) stated that in collectivist culture, people tend to think of themselves as a part of we. This statement also supported by Smetana (2011) that in collectivist culture, the interdependent construal of the self is a big part of the culture. Interdependent construal consists of connectedness with the social context, indirectness in social interactions, a focus on statuses, roles, relationships, and a concern with fitting in. In other words, collectivism simply means that building and maintaining social integrity or harmonious relationship with others is an important matter. 
In reality, there are many Indonesian adolescents who experience a difficult time in building harmonious relationships with others. Not long ago, there was a middle school student who physically attacked her own friend because they had argument in one of social media platforms (Syah, 2016). To prevent these kinds of conflict to happen in the future, adolescents need a positive relational selfesteem.

Even though relational self-esteem is an important aspect that can influence adolescent's ability to adapt with their surroundings (Yomtov et al., 2015), relational self-esteem is rarely studied (Du, King, \& Chi, 2012). In Indonesia, there is still no research regarding relational self-esteem. Most of the research regarding self-esteem mainly focused on general self-esteem. One of the studies about general self-esteem is by Zahra (2014). She studied the relationship between father involvement with high school student's self-esteem in Jakarta Pusat. There are two dimensions of self-esteem, which are selfliking and self-competence. Tafarodi and Swann (in Zahra, 2014) defined self-liking as affective evaluation about oneself, acceptance or rejection based on social value. Moreover, self-competence is defined as an overall sense of oneself as capable, efficient, and in control. Based on these definitions, there is a similarity between self-liking and relational self-esteem, that is, both constructs focus on self-evaluation. However, in relational selfesteem, self-evaluation is derived from a relationship with significant others (family and peers), whereas self-liking is not.

One of the studies of relational self-esteem was completed by Yomtov et al. (2015) regarding the relationship between parental support and relational self-esteem in ninth graders. Parental support entails interaction between the child and parent that show emotional support and warmth (Yomtov et al., 2015). The participants in this study were 662 Latino ninth graders in Los Angeles. Data was collected from self-report survey. The result indicated that adolescent's perception of parental support positively related to adolescent's relational selfesteem. As suggested by Henry (1994), parental support can promote positive evaluation of the self in interaction with others. Additionally, Yomtov et al. (2015) said that children can imitate parental behavior showing support and warmth to others resulting in higher level of relational self-esteem.

Although parental support has positive relation with adolescent's relational self-esteem, there is a slight difference between maternal and paternal support toward adolescent's relational self-esteem. Maternal support was correlated more strongly with relational self-esteem than was paternal support, with correlation coefficient of .64 and .49 , respectively. Lamb (1997) said that in early adolescence, mother involvement tends to manifest in the form of caretaking. On the contrary, fathers tend to spend their leisure time in recreational and goal-oriented activities.

Regarding father involvement, Finley and Schwartz (2004) said that father involvement could be viewed from broader aspect, not only affective aspect but also behavioral aspect. Behavioral aspect includes expressive involvement (caregiving, companionship, sharing activities, emotional development, social development, spiritual development, physical development, and leisure), instrumental involvement (discipline, protecting, providing income, monitoring schoolwork, moral development, developing responsibility, career development, and developing independence), and mentoring/advising involvement (intellectual development, developing competence, mentoring, and giving advice) (Finley \& Schwartz, 2004).

There are many studies regarding father involvement. One of the first is a study by Lamb, Pleck, Charnov, and Levine (1985) who said that father involvement had three components, which are paternal engagement, accessibility (availability), and responsibility. Fathers who engage in direct interaction with their children are available for children, and make sure that their children are taken care of as well as arrange for resources for the children. At the beginning, father involvement is unidimensional, solely as a breadwinner (Lamb, 2010). In Indonesia, father involvement in the form of communication with children, often revolves around few topics, such as career and education (Etikariena, YEAR, as cited in Sarwono, 2012). However, along with the development of research on father involvement, more people recognize that father involvement is multidimensional. Hawkins and Palkovitz (1999) identified that father involvement has several domains, such as caregiving, providing income, disciplining, developing responsibility, and providing companionship.

Initially, father involvement was measured based on father's point of view. However, Finley and Schwartz (2004) adopted children-centered approach that emphasized children's perception of father involvement. Palkovitz (2002) said that father involvement relied on children's perception of influence on children's development. The core of 
child-centered approach is that what most affects children's current and future behavior is children's point of view of their parents (Finley \& Schwartz, 2004). Based on the approach, Finley and Schwartz (2004) developed two instruments to measure child's perception of father involvement, which are Nurturant Fathering Scale and Father Involvement Scale. Nurturant Fathering Scale was designed to measure affective quality of father involvement, including warmth and acceptance. Father Involvement Scale was designed to measure behavior quality of father involvement, divided into two subscales, which are reported as father involvement and desired father involvement. In reported father involvement, participants can rate their father's level of involvement. On the other hand, in desired father involvement, participants rate their expectation of their father's involvement.

In this study, we explored the contribution of perceived father involvement towards relational self-esteem in early adolescence. Proposed hypothesis of this study was that perceived father involvement, which consisted of affective and behavioral aspects, would contribute towards relational self-esteem in early adolescence. The rationale for this study's focus on relational selfesteem was because in early adolescence, children are going through significant social changes, therefore adolescents need positive adjustment ability, which is relational self-esteem (Yomtov et al., 2015). In this study, father involvement viewed from broader aspects, which are affective aspect and behavioral aspect. Father involvement will be measured by Nurturant Fathering Scale and Father Involvement Scale by Finley and Schwartz (2004).

\section{Methods}

\section{Participants}

One hundred and sixty-two middle school students with designated age range 12-15 years old (Mage= 13.95 years old; $\mathrm{SD}=0.83$ ) located in Tanjung Priok, Jakarta Utara participated. The reason why data were obtained in Tanjung Priok, Jakarta Utara was that juvenile delinquency that often happened in there. Because of the juvenile delinquencies is often reported there, Lembaga Musyawarah Kelurahan (LMK) organized socialization targeting towards adolescents in Tanjung Priok ("Penyuluhan Atasi Kenakalan Remaja", 2012). One of juvenile delinquencies, in the form of conflict within social relationship, happened not so long ago and involved a middle school student physically attacking her own friend because of an argument they had in one of social media platforms (Syah, 2016). Therefore, we decided to examine further if delinquencies, in the form of social conflict, really happened because of contributed factor of negative relational selfesteem.

Majority of participants were girls (55.6\%). Participants also came from families consisting of father and mother. Based on parent's characteristics, the majority of participants have fathers from age 41-65 years old (67.3\%) and high school graduates $(55.6 \%)$. On the other hand, the majority of mothers from age 22-40 years old (56.2\%) and high school graduates $(48.1 \%)$. Based on occupation, $24 \%$ of fathers were working as employees in private company, and for the mothers, most were working as housewives. The majority of the fathers (29.6\%) spent 3-5 hour/week of their time with their children

\section{Research Design}

This study used a quantitative research design with structured approach. According to Kumar (2011), in quantitative research, the aim, design, sample, and research question, already determined before the study is conducted. Sampling technique used in this research was non-probability sampling. This was because researchers did not have sampling frame regarding the total number of participants.

\section{Instrument and Measurement}

In this study, relational self-esteem was measured with Relational Self-Esteem Scale by $\mathrm{Du}$ et al. (2012). Relational Self-Esteem Scale measured how individual evaluated their worth when they are in a relationship with significant other. Relational SelfEsteem Scale consisted of two dimensions, which are association with family and best friends as significant others and one's value in relationships with significant others and the value of significant others.

One of the items from the first dimension is "I feel I can have much to offer to my family", and the example of the second dimension is "I am proud of my family." There is no reverse scored items in the instrument. Participants respond to each item based on 4-point Likert scale ( $1=$ strongly disagree; $4=$ strongly agree). Du et al. (2012) did a Confirmatory Factor Analyses (CFA) to see if Relational SelfEsteem can be considered as unidimensional or multidimensional. Based on CFA and reliability test, it was found that Relational Self-Esteem was a good model fit as a unidimensional construct. 
Therefore, in this study, the two dimensions from Relational Self-Esteem Scale were totaled to provide one end score.

Relational Self-Esteem Scale was adapted to Indonesian language. Afterwards, reliability and validity tests were conducted with 30 middle school students. Based on reliability test, Relational SelfEsteem Scale has .69 Cronbach Alpha score, which falls into minimally acceptable criteria based on Everitt (2002). For validity test, corrected item-total correlation was obtained. Based on corrected itemtotal correlation, there were two items (item 4 and 8 ) that did not pass the standard score for validity, which is .2 (Everitt, 2002). Therefore, researcher consulted the two items with an expert.

Perceived father involvement was measured using Nurturant Fathering Scale and Father Involvement Scale-Reported. Nurturant Fathering Scale (NFS) was used to measure affective quality of father involvement. NFS has 9 items measured on a 5point Likert scale. NFS does not have any reverse score. Father Involvement Scale-Reported (FIS-R) has 20 items to measure behavioral quality of father involvement. Each item was measured on a 5-point Likert scale with no reverse score.

FIS-R has three subscales, which are instrumental involvement, expressive involvement, and mentoring/advising involvement. Instrumental involvement (8 items) consists of career development, moral development, developing responsibility, developing independence, providing income, being protective, discipline, and school or homework domains. Expressive involvement (8 items) consists of social development, spiritual development, physical development, leisure, sharing activities, caregiving, companionship, and emotional development. For the third subscale, which is mentoring involvement (4 items), it consists of developing competence, mentoring/teaching, intellectual development, and advising domains. Even though each item represents different type of involvement, but to calculate the end score, all of the items must be totaled into one score.

NFS and FIS-R were first adapted by Ambarsari (2013) to Indonesian language. The adapted version of NFS and FIS-R obtained high scores of reliability, .91 (NFS) and .95 (FIS-R) (Ambarsari, 2013). Corrected item-total correlation was conducted to obtain internal consistency for each measurement. Both NFS and FIS-R have internal consistency score above .2. Ambarsari's (2013) adaptation version was addressed for high school students. Therefore, in 2014, Hayuning Zaskya Nugrahani adapted Father Involvement ScaleReported for middle school students. This adapted version of FIS-R obtained .91 reliability score and internal consistency above .2 (Nugrahani, 2014). In this study, Ambarsari's adaptation version of NFS and Nugrahani's adaptation version of FIS-R was used.

In this study, researcher also conducted reliability and validity test for NFS and FIS-R. Reliability and validity test was performed on 33 middle school students, but only 30 questionnaires that can be analyzed. Two of them did not finish all the items on the questionnaire, and the rest did not meet the criteria decided by the researchers. Based on reliability test, reliability scores were obtained, .76 on NFS and .88 on FIS-R. On the other hand, validity scores for internal consistency on NFS and FIS-R were above 2 .

Several analytical techniques were used in this study. Descriptive statistics were used to analyze demographic characteristics, such as age, gender, education, and occupation of participants and their parents. Multiple regression was used to determine whether perceived father involvement has a contribution towards relational self-esteem or not. Independent sample t-test and one-way ANOVA were used to compare the means of variables based on demographic characteristics

\section{Procedure}

The study was conducted on 26-28 April 2017 in three middle schools located in Tanjung Priok, Jakarta Utara. The data was obtained by giving one questionnaire containing six instruments. Before participants completed the questionnaire, they received an explanation about the purpose about the study. The researchers also gave an explanation about the instructions for each of the instruments. After the participants completed the questionnaire, they received a reward as a token of gratitude. 


\section{Results}

A preliminary check of the assumption of normality of the data was tested by examination of the unstandardized residuals. Using KolmogorovSmirnov Test, it was known that the distribution of data was normal $(\mathrm{D}(162)=.809, p>.05)$. Afterwards, researchers also checked that there was no multicollinearity. Based on Variance Inflation Factor (VIF), the independent variables, which are affective aspect measured by Nurturant Fathering Scale and behavioral aspect measured by Father Involvement Scale, were not highly correlated with each other.

Before the contribution of perceived father involvement towards relational self-esteem was calculated, descriptive data of all variables were obtained.

Table 1. Descriptions on Research Variables

\begin{tabular}{ccccc}
\hline & $\mathbf{M}$ & SD & $\begin{array}{c}\text { Max } \\
\text { Score }\end{array}$ & $\begin{array}{c}\text { Min } \\
\text { Score }\end{array}$ \\
\hline $\begin{array}{c}\text { Nurturant } \\
\text { Father }\end{array}$ & 3.63 & .67 & 4.78 & 1.89 \\
$\begin{array}{c}\text { Involvement } \\
\text { Reported } \\
\text { Father }\end{array}$ & 3.40 & .63 & 5.00 & 1.65 \\
$\begin{array}{c}\text { Involvement } \\
\text { Relational } \\
\text { Self-Esteem }\end{array}$ & 3.15 & .36 & 3.75 & 2.00 \\
\hline
\end{tabular}

As we can see from Table 1., participants reported that their fathers showed more affective aspect of perceived father involvement or nurturant father involvement $(\mathrm{M}=3.63)$ rather than behavioral aspect of perceived father involvement or reported father involvement $(M=3.40)$.

Table 2. Contribution of Perceived Father Involvement towards Relational Self-Esteem

\begin{tabular}{lccccc}
\hline Variables & $\mathrm{F}$ & $\mathrm{R} 2$ & $\mathrm{~B}$ & $\mathrm{SE} \mathrm{B}$ & Sig. \\
\hline \multicolumn{5}{c}{ Outcome: Relational Self-Esteem } \\
NFS & 7.13 & .064 & .137 & .045 & $.003^{*}$ \\
FIS-R & & & .002 & .047 & .965 \\
\hline
\end{tabular}

FIS-R = Father Involvement Scale (Reported); NFS = Nurturant Fathering Scale

*significant on level .01

Based on Table 2., Nurturant Fathering Scale, which measured affective quality of perceived father involvement, had a contribution to relational selfesteem $\left(\mathrm{R}^{2}=.064, p<.01\right)$. On the contrary, Father Involvement Scale-Reported, which measured behavioral aspect of perceived father involvement, had no significant contribution towards relational self-esteem. $(p>.05)$.

\section{Discussion \& Conclusion}

Based on the result, it can be concluded that affective quality of perceived father involvement significantly contributed to relational self-esteem. It means that parental support and warmth may increase positive relational self-esteem. The result is consistent with previous study by Yomtov et al. (2015). The result indicated that parental support and warmth correlated with adolescent's relational selfesteem. Support and warmth from parents can make children feel loved (Cooley, YEAR, as cited in Yomtov et al., 2015). The feeling of being loved becomes internalized, therefore children have a more positive relational self-esteem. Moreover, Yomtov et al. (2015) said that adolescents might model parental support and warmth in relations with others, possibly resulting in more positive relational self-esteem.

Positive relational self-esteem can be obtained not only from positive evaluation about self, but also from positive evaluation about significant others. Henry (1994) said that parental support increases children's family life satisfaction. Family life satisfaction is a positive perspective about family members (Henry, Ostrander, \& Lovelace, 1992). Therefore, affective quality, such as support can increase the possibility of positive relational selfesteem.

In this study, it was also known that behavioral aspect of perceived father involvement, measured by Father Involvement Scale, had no significant contribution towards relational self-esteem. The result can be explained by a previous study by Patterson, Pryor, and Field (1995). It said that physical closeness between parents and children can decrease as the children get older, but not with emotional closeness. Emotional closeness between parents and children has a positive correlation with psychological well-being, which self-esteem is included. Amato (YEAR, as cited in William \& Kelly, 2005) said that parental involvement, especially father involvement; in the form of emotional support and caregiving have positive effect for children, for example improvement in social competence.

In the process of making this research, there were some limitations. There were two items from the adaptation of Relational Self-Esteem Scale that have corrected item-total correlation below .2. Therefore, future research should conduct a new adaptation that has better score in corrected item-total correlation. Regarding process of obtaining the data, future researcher should make a better planning for time estimation. Therefore, participants can fill in the 
questionnaire effectively. For this reason, further research should also measure another variable that might contribute to the correlation between relational self-esteem and perceived father involvement, such as locus-of-hope.

\section{References}

Adamsons, K., \& Johnson, S. K. (2013). An updated and expanded meta-analysis of nonresident fathering and child well-being. Journal of Family Psychology, 27(4), 589-599. doi: $10.1037 / \mathrm{a} 0033786$

Amato, P. R. (1998). More than money? Men's contributions to their children's lives. In A. Booth \& A. C. Crouter (Eds.), Men in families: When do they get involved? What difference does it make? (pp. 241-278). Mahwah, NJ: Erlbaum.

Ambarsari, S. (2013). Hubungan antara keterlibatan ayah dan kompetensi sosial pada remaja madya. Skripsi. Fakultas Psikologi Universitas Indonesia, Depok.

Chen, S., Boucher, H., \& Kraus, M. W. (2011). The relational self. In Handbook of identity theory and research (pp. 149175). New York: Springer.

Du, H., King, R. B., \& Chi, P. (2012). The development and validation of the Relational Self-Esteem Scale. Scandinavian Journal of Psychology, 53(3), 258-264. doi: 10.1111/j.1467-9450.2012.00946.x

Du, H., Bernardo, A. B., \& Yeung, S. S. (2015). Locus-of-hope and life satisfaction: The mediating roles of personal selfesteem and relational self-esteem. Personality and Individual Differences, 83, 228-233. doi 10.1016/j.paid.2015.04.026

Du, H., Li, X., Chi, P., Zhao, J., \& Zhao, G. (2014). Relational self-esteem, and social support in children affected by HIV. Journal of health psychology, 20(12), 1568-1578. doi: $10.1177 / 1359105313517276$

Erath, S. A., Flanagan, K. S., \& Bierman, K. L. (2007). Social anxiety and peer relations in early adolescence: Behavioral and cognitive factors. Journal of abnormal child psychology, 35(3), 405-416. doi:10.1007/s10802-0079099-2

Everitt, B., \& Skrondal, A. (2002). The Cambridge dictionary of statistics (Vol. 106). Cambridge: Cambridge University Press.

Feiring, C., \& Lewis, M. (1991). The transition from middle childhood to early adolescence: Sex differences in the social network and perceived self-competence. Sex Roles, 24(7), 489-509. doi: 10.1007/BF00289335

Finley, G. E., \& Schwartz, S. J. (2004). The father involvement and nurturant fathering scales: Retrospective measures for adolescent and adult children. Educational and Psychological Measurement, 64(1), 143-164.doi: 10.1177/0013164403258453

Fuligni, A. J., \& Eccles, J. S. (1993). Perceived parent-child relationships and early adolescents' orientation toward peers. Developmental psychology, 29(4), 622.

Hawkins, A. J., \& Palkovitz, R. (1999). Beyond ticks and clicks: The need for more diverse and broader conceptualizations and measures of father involvement. Journal of Men's Studies, 8, 11-32. doi: 10.3149/jms.0801.11

Henry, C. (1994). Family system characteristics, parental behaviors, and adolescent family life satisfaction.Family Relations, 43, 447-455.doi: 10.2307/585377
Henry, C., Ostrander, D., \& Lovelace, S. (1992). Reliability and validity of the Adolescent Family Life Satisfaction Index. Psychological Reports, 70, 1223-1229.

Kumar, R. (2011). Research methodology: A step-by-step guide for beginners (3rd ed). London: SAGE Publications.

Lamb, M. E. (1997). Fathers and child development: An introductory overview and guide. In M. E. Lamb (Ed.). The role of the father in child development (3rd ed, pp. 1-18, 309-313). New York: Wiley.

Lamb, M. E. (2010). How do fathers influence children's development? Let me count the ways. In: Lamb, M. editors. The role of father in child development (5th ed., p. 1-26). Hoboken, NJ: John Wiley \& Sons, Inc.

Lamb, M. E., Pleck, J. H., Charnov, E. L., \& Levine, J. A. (1985). Paternal behavior in humans. American zoologist, 883-894. doi: 10.1093/icb/25.3.883

NICHD Early Child Care Research Network (2000). Factors associated with fathers' caregiving activities and sensitivity with young children. Journal of Family Psychology, 14, 200-219.

Nugrahani, H. Z. (2014). Hubungan antara prestasi akademik dan keterlibatan ayah pada remaja sekolah menengah pertama. Skripsi. Fakultas Psikologi Universitas Indonesia, Depok

Patterson, J., Pryor, J., \& Field, J. (1995). Adolescent attachment to parents and friends in relation to aspects of self-esteem. Journal of Youth and Adolescence, 24, 365376.

Pleck, J., \& Masciadrelli, B. (2004). Paternal involvement by U.S residential fathers: Levels, sources, and consequences. In: Lamb, M. (Ed). The role of the father in child development $\left(4^{\text {th }}\right.$ ed, p. 222-271). New York: John Wiley $\&$ Sons.

Rohner, R. P., \& Veneziano, R. A. (2001). The importance of father love: History and contemporary evidence. Review of General Psychology, 5(4), 382. doi: 10.1037/10892680.5.4.382

Santrock, J. (2014). Adolescence (15 ${ }^{\text {th }}$ ed). New York: McGrawHill.

Sarwono, S. (2012). Psikologi remaja. Jakarta: PT Rajagrafindo Persada.

Syah, M. (2016). Saling ejek di media sosial, remaja di Priok silet temannya, Liputan 6. Diakses dari http://news.liputan6.com/read/2618171/saling-ejek-dimedia-sosial-remaja-di-priok-silet-temannya

Tong, Y., \& Song, S. (2004). A study on general self-efficacy and subjective well-being of low SES-college students in a Chinese university. College Student Journal, 38(4), 637 643.

Williams, S. K., \& Kelly, F. D. (2005). Relationships among involvement, attachment, and behavioral problems in adolescence: Examining father's influence. The Journal of Early Adolescence, 25(2), 168-196. doi: $10.1177 / 0272431604274178$

Yomtov, D., Plunkett, S. W., Sands, T., \& Reid, A. (2015) Parenting and ninth graders' self-efficacy and relational self-esteem in Latino immigrant families. Family and Consumer Sciences Research Journal, 43(3), 269-283.doi: $10.1111 /$ fcsr.12102

Zahra, F. (2014). Hubungan antara keterlibatan ayah dan selfesteem remaja pada siswa SMA di Jakarta Pusat. Skripsi. Fakultas Psikologi Universitas Indonesia, Depok. 